\title{
A Study on Awareness and Attitude Towards Islamic Banking in Tirupattur District
}

\section{OPEN ACCESS}

Manuscript ID:

COM-2021-09044148

Volume: 9

Issue: 4

Month: October

Year: 2021

E-ISSN: 2582-6190

Received: 18.07.2021

Accepted: 20.8.2021

Published: 01.10.2021

Citation:

Maria John Joseph, KA, and D. Mahalakshmi. "A Study on Awareness and Attitude Towards Islamic Banking in Tirupattur District." ComFin Research, vol. 9, no. 4, 2021, pp. 1-6.

DOI:

https://oi.org/10.34293/

commerce.v9i4.4148

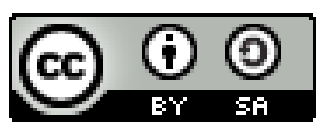

This work is licensed under a Creative Commons Attribution-ShareAlike 4.0 International License

\author{
K. A. Maria John Joseph \\ Research Supervisor, Associate Professor \& Head \\ Sacred Heart College (Autonomous), Tirupattur, Tamil Nadu, India
}

\section{Mahalakshmi}

Assistant Professor, PG and Research Department of Commerce

Islamiah women's Arts and Science College, and Research Scholar (Part Time)

Sacred Heart College (Autonomous), Tirupattur, Tamil Nadu, India

\begin{abstract}
The banking system in every country is based on the interest system. Interest-bearing money is almost like the law of nature where money generates money but alternative banking system called Islamic banking. Islamic banking follows Islamic ethical principle which appears very different from those of the conventional western banking finance model.

In this study, the data has been obtained through both primary and secondary sources. The secondary data were collected from journals, magazines, and the Holy Quran. The fresh data were collected through questionnaires from Tirupattur District. The research design used for this study is descriptive type. The Sampling design used for the study was the convenience sampling technique. The percentage analysis was used for the study.

The Islamic banking system in India was introduced for both Muslim and Non-Muslim customers. Few of the Muslim customers have an account in Islamic banking. Most of the customers do not have awareness about the Islamic bank. This study aims to discover awareness and attitude about Islamic banks, both Muslims and non-Muslim in Tirupattur District. The main objective of Islamic Banking is to retain their existing customers and attract new customers by creating awareness about their banking system. This banking system follows the interest-free principles under Islamic Law.
\end{abstract}

Keywords: Islamic banking, Customer awareness, Attitudes, Islamic principles, Islamic law, Interest system.

\section{Introduction}

Islamic Banking is a banking system by the Shariat. In Islam, money has no intrinsic value-money. Therefore, it cannot be sold at a profit and can be used as er Shariat only. The Islamic Law or Shariat prevents paying any rent fee (called riba) for a specific period. It also prohibits any sort of finance in a business that is considered haraam or against the principles of Islam. It is largely thought that these principles have been derived from the Quran and have been in since then. Allah destroys interest and increases charity, and Allah does not like every sinning disbeliever (Surah al- Baqarah verse 276)

Islamic Banks work on the principles of Riba (interest-free). This prohibition of interest was based upon the Sharia ruling. Since Muslims cannot receive or pay interest, they cannot conduct business with conventional banks (Gerrard and Cunningham,1997).To service this niche market, Islamic financial institutions have contracted a range of halal interest-free financing instruments that conform to Sharia ruling, and therefore are acceptable to their clients. 


\section{Islamic Banking Principles}

- Predetermined loan repayments as interest (riba) are prohibited

- Profit and loss sharing is at all heart of the Islamic system

- Making money out of money is unacceptable. All financial transactions must be asset backend

- No speculative

- Only approved contracts are accepted(Sharia)

- Contracts are Sacred

\section{Modes of Finance \\ Conventional Bank}

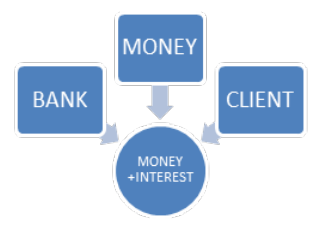

\section{Islamic Bank}

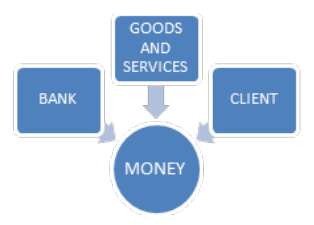

\section{Differences between Islamic and Conventional Banking}

Islamic banking has based the prohibition of interest, founded not on economics but religious convictions (Ghannadian \& Goswami, 2004). The basic principle of Islamic banking is the prescription of matter or "riba," where banks are not demanded to charge interest for lending money to customers; money lending should be interest-free. Not charging interest needs the Islamic banks to finance investment projects through profit and loss sharing.

According to Islamic banking principles, the prevailing method of charging interest in the conventional banking system is an injustice to borrowers. The interest on loans has to be paid irrespective of the consequences of their business (Dusuki \& Abdullah, 2007). In other words, Islamic banking deals with the creation of equity (through profit and loss sharing schemes) and rental income, whereas the pillar of conventional banking is debt through interest (Patel, 2006)

Table 1: Differences between Islamic Banking and Conventional Banks

\begin{tabular}{|l|l|}
\hline \multicolumn{1}{|c|}{ Conventional banking system } & \multicolumn{1}{c|}{ Islamic banking system } \\
\hline Charge interest on loans. & $\begin{array}{l}\text { Do not charge interest. Riba (interest) is an unjust return, profit or usury. } \\
\text { The term applies to any financial gain by the lender as a condition of a } \\
\text { loan and in commodity trade. It also applies to any disparity in quantity } \\
\text { or time of delivery, as such transactions are illegal under Islamic law } \\
\text { (Martins, 1997; Chong\&Liu, 2008). } \\
\text { Zero-return loans. Prohibits the charging or receiving of interest. A } \\
\text { unique feature of Islamic banking is its profit-and-loss sharing (PLS) } \\
\text { paradigm, which is based mainly on the profit-sharing and Musharaka } \\
\text { (joint venture) concepts of Islamic contracting (Chong\&Liu,2008). }\end{array}$ \\
\hline Principal stakeholders are shareholders. & $\begin{array}{l}\text { The principal stakeholder is God. The aim is to serve God, while the } \\
\text { stakeholders are the clients and the general public. Clients are partners, } \\
\text { and the decisions are in the interest of society. }\end{array}$ \\
\hline $\begin{array}{l}\text { Support arms industries and industries that } \\
\text { pollute the environment and exploit children. }\end{array}$ & $\begin{array}{l}\text { Sharia law places restrictions on business activities. The law further } \\
\text { prohibits trading in alcohol, tobacco, products that contain pork, } \\
\text { defense, and weapon production and certain entertainment activities } \\
\text { like gambling, and pornography (Chong \& Liu, 2008). }\end{array}$ \\
\hline $\begin{array}{l}\text { Gives loans to whoever has a guarantor or } \\
\text { collateral. }\end{array}$ & $\begin{array}{l}\text { Gives loans to those who need loans. You do not need collateral to get } \\
\text { a loan. }\end{array}$ \\
\hline
\end{tabular}




\begin{tabular}{|c|c|}
\hline $\begin{array}{l}\text { Decisions are made in the interest of } \\
\text { shareholders. }\end{array}$ & $\begin{array}{l}\text { Islamic principles advocate for an economic system in which all forms } \\
\text { of exploitation are eliminated. The other principle is Mudarbah (trust } \\
\text { financing), a profit-sharing agreement between two parties in which } \\
\text { one provides finance and the other provides entrepreneurial and } \\
\text { management skills. Profits are divided according to a predetermined } \\
\text { ratio. } \\
\text { Losses are borne by the provider of capital. }\end{array}$ \\
\hline $\begin{array}{l}\text { Designed for those who have money and who } \\
\text { do not care what it is used for Consumers } \\
\text { have no opportunity to choose where money } \\
\text { is invested. Provides no information about } \\
\text { what it does with depositors' money. }\end{array}$ & $\begin{array}{l}\text { Islamic banks have an interest in how the money borrowed is used. The } \\
\text { Islamic banks have a stake in financial activities so that money is not } \\
\text { used for economic activities that are injurious to society. } \\
\text { Those who lend to the Islamic banks expect the banks not to invest } \\
\text { their money in business activities that are not Shariah-compliant. } \\
\text { Islamic banks invest only in business activities that are Shariah- } \\
\text { compliant. }\end{array}$ \\
\hline $\begin{array}{l}\text { Its investment rewards companies even if } \\
\text { they act irresponsibly. }\end{array}$ & $\begin{array}{l}\text { Islamic banks share profits and losses. Murabaha (cost-plus financing) } \\
\text { is a contract sale between the bank and its client to sell goods at a price } \\
\text { that includes a profit margin for both parties. As a financing technique, } \\
\text { it involves the purchasing of goods by the bank as requested by its } \\
\text { client. }\end{array}$ \\
\hline $\begin{array}{l}\text { Seeks to satisfy demand. Conventional } \\
\text { banks open branches in those areas that have } \\
\text { sufficient demand but not needs. They open } \\
\text { accounts for individuals whose income levels } \\
\text { can create demand for banking services and } \\
\text { not those who might need such accounts. }\end{array}$ & Seeks to satisfy a need \\
\hline
\end{tabular}

Source: adapted from Saidi (2007) and Martin (1997).

\section{Review of Literature}

Yusuf and Shamsuddin carried out a study to determine the character of Muslims staying outside the Islamic world by carrying out a purposive random sampling of 128 respondents from Leicester, UK. They found out that Muslims had a positive approach towards Islamic finance as they were willing to change from the traditional system into the Islamic finance system.

Alam used a study approach on an interestfree financial institution-Islamic Bank Bangladesh Limited (IBBL) to see how Islamic banking practices differ from a conventional bank and see how these banks contribute towards small and rural sectors. While discussing various aspects of the IBBL, the author has shown understandable how interestfree banks function besides many established conventional banks. An introduction of Islamic banking systems and several financing methods and techniques used by Islamic banks are discussed, along with a short history of IBBL-.
Erol and El-Bdour (1989) discovered that the most important criteria considered by consumers in bank selection are fast and efficient services, a bank's reputation and image, and confidentially.

Othman \& Owen (2001) confirmed a strong link between service quality and customer satisfaction. As a result, Islamic banks must pay close attention to this factor and begin to think strategically to satisfy their customers by providing high-quality products and services. In this study of Malaysian banking consumers.

Hamid and Nordin (2001) found a high awareness of Islamic banking but a poor knowledge of specific Islamic banking products, including a poor understanding of the difference between Islamic and conventional banks. They also believed that better consumer education assists in making people more aware of Islamic banking products.

Dusuki and Abdullah (2007) found that the selection of Islamic banks in Malaysia is based on a combination of Islamic and financial reputation and the quality of services offered by each bank. 
Bashir, Machali \& Mwinyi (2012) found that the success of any product and service highly depends on customer acceptance and satisfaction. High-quality service helps generate customer satisfaction, customer loyalty and growth of market share by soliciting new customers. It also improves productivity and financial performance.

Badara et al. (2013) surveyed in Nigerian Islamic Bank and found that the relation of customer satisfaction of Islamic banks is significant with assurance and responsiveness dimensions. In their study, the other proportions were found to be insignificant.

Khafafa and Shafii (2013), in their study in Libya, found the power indicator is the responsiveness dimension of service quality followed by reliability, empathy, assurance, and tangibility dimensions, respectively.

Altwijry and Abduh (2013) have surveyed customer satisfaction and switching behavior in Saudi Arabia. The study suggested that banks should adopt internet banking in all their transactions, should check shariah-compliant services, pay attention to confidentiality and improve accuracy as well as the level of organizational performance.

Abduh and Othman (2014) surveyed in UAE found that performance of attributes (viz., speedy approval of financial proposals, Islamic banking environment, easy process of opening new accounts, transactions costs of banking services and products) need to be improved. The study suggested introducing and keeping up-to-date internet technology for customer services.

Alotaibi and Lone (2016) have undergone a study that many economies across the globe are adopting Islamic banking not because of religiosity but because of the economic advantages that this banking offers. Central banks of many countries are changing or amending their banking laws to make Islamic banking legally feasible to flourish in secular countries. Even in academia, many universities are introducing courses related to Islamic finance to overcome the shortages of Islamic finance experts globally in general and Saudi Arabia in particular.

\section{Research Methodology}

The data was collected from both the sources, primary and secondary. The original Data was collected through a structured questionnaire from the customers of Islamic Bank, Tirupattur district. The secondary data was collected from journals, magazines, newspapers, etc. The sampling technique used in this study was convenience sampling, and percentage analysis was used for analyzing the collected data.

\section{Statement of the Problem}

Islamic Banking System is a recent evolution. The Islamic Finance System has to evolve with time without violating the fundamentals of the Islamic Finance System as per the Shariat. This system was introduced in India for both Muslim and Non-Muslim customers. Only a few customers have accounts in these banks due to unawareness. Hence, this study attempts to find out the awareness and attitude towards Islamic Banking in Tirupattur District.

\section{Need of the Study}

Islamic Banking is proposing more competition and solidarity with low-income groups and their vast savings and expenditures. It recognizes the factors which are directly linked with customer awareness and attitude. This research is to examine the level of awareness, understanding and perceptions of nonMuslims about Islamic banking.

\section{Findings}

- $64 \%$ of the respondents are female.

- $68 \%$ of the respondents belong to the age group between 25 to 45 years.

- $63 \%$ of the respondents are postgraduates.

- A Maximum (77\%) of them belongs to private companies.

- The Majority $(80 \%)$ of them have a salary range of Rs15, 000 to Rs30, 000.

- $75 \%$ of the Muslim respondents have an account in the Islamic Bank.

- Islamic Banking doesn't support illegal business $(63 \%)$

- $73 \%$ of the people do not have any awareness about Islamic banking.

- The main motive of Islamic banking is to improve the welfare of society.

- Half of the respondents already have an account 
in a conventional bank, so they follow that account itself.

- $25 \%$ of the respondents do not have any knowledge about Islamic banking.

- $63 \%$ of the respondents said that Islamic banking was open in they immediately opened an account.

- $35 \%$ of the respondents will react based on the market response after opening an account in Islamic banking.

- $62 \%$ of the respondents believe in the principle and ethics of Islamic law; the interest is not accepted by the believers.

- Most of the person says deposit all the money in Islamic banking comes to a doorstep because the profit will be helpful for poor people.

\section{Limitation}

- This study was limited to the Tirupattur area.

- The research study covered the awareness and cultural attitude of the customers towards Islamic banking.

\section{Suggestion}

In the current study, it is found that Islamic banking has a low level of awareness among the respondents. However, the attitude towards the adoption of Islamic Banking seems encouraging, as reflected in the research.

The awareness should be spread to the whole society. More branches should be opened, which could be very helpful to society in the present scenario.

\section{Conclusion}

Islamic banking is a succinct guide to the key characteristics of Islamic banking, highlighting how these differ from conventional banking. Islamic banking only supports legal business. It is very much profitable to poor people because it has no interest due to principles and ethics.

\section{References}

Abduh, Muhamad, and Abdullah A.M. Othman. "Service Quality Evaluation of Islamic Banks in UAE: An Importance-Performance Analysis Approach." Journal of Islamic Economics, Banking and Finance, vol. 10, no.
2, 2014, pp. 103-113.

Alotaibi, Khalid Abdullah, and Fayaz Ahmad Lone. "Islamic Banking and Finance Education: A Comparative Study of Saudi Arabia and the UK." International Journal of Economic Research, vol. 13, no. 7, 2016.

Altwijry, Othman Ibrahim, and Muhamad Abduh.

"Customer Satisfaction and Switching Behavior in Saudi Islamic Banks: An Exploratory Study." Journal of Islamic Finance, vol. 2, no. 2, 2013, pp. 17-25.

Badara, Mu'azu Saidu, et al. "Direct Effect of Service Quality Dimensions on Customer Satisfaction and Customer Loyalty in Nigerian Islamic Bank." Management, vol. 3, no. 1, 2013, pp. 6-11.

Banu, Shakeela. "Islamic Banking in India." Global Journal of Finance and Management, vol. 6, no. 3, 2014, pp. 259-264.

Bashir, Mohammad Sharif, et al. "The Effect of Service Quality and Government Role on Customer Satisfaction: Empirical Evidence of Microfinance in Kenya." International Journal of Business and Social Science, vol. 3, no. 14, 2012, pp. 312-319.

Dusuki. Asyraf Wajdi, and Nurdianawati Abdullah. "Why do Malaysian Customers Patronize Islamic Banks?" International Journal of Bank Marketing, vol. 25, no. 3, 2007, pp. 142160.

Erol, Cengiz, and Radi El-Bdour. "Attitudes, Behaviour, and Patronage Factors of Bank Customers towards Islamic banks." International Journal of Bank Marketing, vol. 7, no. 6, 1989, pp. 31-37.

Faisal, Mohammad, et al. Awareness of Islamic Banking in India - An Empirical Study.

Gobena, Gemechu Abera. "Attitude of School Principals, Supervisors and Mentees towards Action Research as Reflective Practices." International Journal of Instruction, vol. 10, no. 1, 2017, pp. 3-20.

Hamid, Abdul and Norizaton Nordin. "A Study on Islamic Banking Education and Strategy for the New Millennium - Malaysian Experience." International Journal of Islamic financial Services, vol. 2, no. 4, 2001. 
Kettell, Brian. Introduction to Islamic Banking and Finance. Islamic Banking Training, 2008.

Khafafa, Ali Joma, and Zurina Shafii. "Measuring the Perceived Service Quality and Customer Satisfaction in Islamic Bank Windows in Libya based on Structural Equation Modelling (SEM)." Afro Eurasian Studies, vol. 2, no. 1 \& 2, 2013, pp. 56-71.

Othman. Abdul Qawi, and Lynn Owen. “Adopting and Measuring Customer Service Quality in Islamic Banks: A Case Study in Kuwait Finance House." International Journal of
Islamic Financial Services, vol. 3, no. 1, 2001.

Rao, Seema. "What is Islamic Banking and Why does the RBI Want it in India?" Scroll.in, 2016.

Saini, Yvonne, et al. "Consumer Awareness and Usage of Islamic Banking Products in South Africa." SAJEMS, 2011, pp. 298-313.

Yusuf, Mohd. Effandi, and Ahmad Shamsuddin. "Muslim Consumers' Attitude towards Islamic Finance Products in a Non-Muslim Country.” Jurnal Kemanusiaan, pp. 94-103.

\section{Author Details:}

Dr. K. A. Maria John Joseph, Research Supervisor, Associate Professor \& Head, Sacred Heart College (Autonomous), Tirupattur, Tamil Nadu, India, Email ID: Mahacute1986@gmail.com

D. Mahalakshmi, Assistant Professor,PG and Research Department of Commerce, Islamiah women's Arts and Science College and Research Scholar (Part Time), Sacred Heart College (Autonomous), Tirupattur, Tamil Nadu, India 